\title{
HDAC3 Is a Negative Regulator of Cocaine-Context- Associated Memory Formation
}

\author{
George A. Rogge, Harsimran Singh, Richard Dang, and Marcelo A. Wood \\ Department of Neurobiology and Behavior; Center for the Neurobiology of Learning and Memory; University of California, Irvine, California 92697-3800
}

Cocaine-induced neuroplasticity mediated by histone acetylating and deacetylating enzymes may contribute to addiction-like behaviors. For example, overexpression of histone deacetylases (HDACs) 4 or 5 in the nucleus accumbens suppresses cocaine-induced conditioned place preference (CPP) acquisition in mice. HDAC4 and HDAC5 are known to interact with HDAC3, but the role of HDAC3 in cocaineinduced behaviors has never been examined. In this study, we address the hypothesis that HDAC3 is a negative regulator of cocainecontext-associated memory formation in mice. We examined the role of HDAC3 during the conditioning phase of CPP, when the mouse has the opportunity to form an associative memory between the cocaine-paired context and the subjective effects of cocaine. To address this hypothesis, $\mathrm{Hdac} 3^{\text {flox/flox }}$ and $\mathrm{Hdac} 3^{+/+}$mice (generated from a C57BL/6 background) were infused into the nucleus accumbens with adeno-associated virus expressing Cre recombinase to create focal, homozygous Hdac 3 deletions. $H d a c 3^{\text {flox/flox }}$ mice exhibit significantly enhanced CPP acquisition, which is correlated with increased gene expression during the consolidation phase of acquisition. Increased gene expression of $c$-Fos and $\mathrm{Nr} 4 \mathrm{a} 2$ is correlated with decreased HDAC3 occupancy and increased histone $\mathrm{H} 4$ lysine 8 acetylation at their promoters. The results from this study demonstrate that HDAC3 negatively regulates cocaine-induced CPP acquisition.

\section{Introduction}

Drugs of abuse strengthen associations between drug-contextassociated cues and the drug's reinforcing effects (Everitt and Robbins, 2005; Levine et al., 2005; Hyman et al., 2006). It is hypothesized that similar molecular mechanisms responsible for long-term memory formation also participate in the formation of long-term, cocaine-context-associated memories (Nestler, 2002; Hyman, 2005; Everitt et al., 2008). An underlying molecular mechanism of both cocaine-induced neuroplasticity associated with addiction (Kumar et al., 2005; Renthal et al., 2007; McClung and Nestler, 2008; Malvaez et al., 2011; Benekareddy et al., 2012; for review, see Rogge and Wood, 2012) and long-term memory formation (Swank and Sweatt, 2001; Levenson et al., 2004; Fischer et al., 2007; Vecsey et al., 2007; for review, see Peixoto and Abel, 2012) is histone acetylation, a form of chromatin modification.

Histone acetylation modulates histone-DNA interactions via histone-acetyltransferases (HATs), which usually facilitate tran-

\footnotetext{
Received Sept. 19, 2012; revised Feb. 2, 2013; accepted March 2, 2013.

Author contributions: G.A.R., H.S., R.D., and M.A.W. designed research;G.A.R., H.S., and R.D. performed research; G.A.R., H.S., R.D., and M.A.W. analyzed data; G.A.R. and M.A.W. wrote the paper.

This work was supported by the National Institute on Drug Abuse (Grant \#R01DA025922 to M.A.W. and K.M.L., multiple principal investigators; Grant \#R21DA031989 to M.A.W.) and the National Institute of Mental Health (Grant \#R01MH081004 to M.A.W.). G.A.R. received training grants from the National Institute of Neurological Disorders and Stroke (T32 Grant \#NS045540; principal investigator, Tallie Z. Baram) and the National Institute on Drug Abuse (Grant \#F32DA031520). We thank Dr. Mitch Lazar for providing genetically modified Hdac $3^{\text {flox/flox }}$ mice, Drs. Susan McQuown, Melissa Malvaez, Alex Pevzner, and Monica Multani for technical and intellectual contributions, and Dr. Matt Lattal for critical discussion.

The authors declare no competing financial interests.

Correspondence should be addressed to Marcelo A. Wood, University of California, Irvine, Department of Neurobiology and Behavior, Center for the Neurobiology of Learning and Memory, 301 Qureshey Research Laboratory, Irvine, CA 92697-3800. E-mail: mwood@uci.edu.

DOI:10.1523/JNEUROSCI.4472-12.2013

Copyright $\odot 2013$ the authors $\quad 0270-6474 / 13 / 336623-10 \$ 15.00 / 0$
}

scription, and histone deacetylases (HDACs), which usually repress transcription (Kouzarides, 2007). In the hippocampus, the HAT CREB-binding protein is a critical, positive regulator of long-term memory formation (Alarcón et al., 2004; Korzus et al., 2004; Wood et al., 2005; Barrett et al., 2011). In the nucleus accumbens (NAc), CREB-binding protein was recently found to mediate acute cocaine-induced histone acetylation, gene expression, and conditioned place preference (CPP) acquisition (Malvaez et al., 2011).

Like HATs, HDACs are also involved in both long-term memory formation and CPP acquisition. In the NAc, HDAC4 and HDAC5 are negative regulators of CPP acquisition (Kumar et al., 2005; Renthal et al., 2007; Taniguchi et al., 2012). Similarly, HDAC2 and HDAC3 are negative regulators of memory formation (Guan et al., 2009; McQuown et al., 2011). Interestingly, HDAC3, which is enriched in the mouse NAc (Renthal et al., 2007), functions in vitro with HDAC4 or HDAC5 in multiprotein transcriptional repressor complexes (Fischle et al., 2002, Karagianni and Wong, 2007; Lahm et al., 2007). Therefore, HDAC3, in association with HDAC4 and/or HDAC5 in the NAc, may be involved in CPP acquisition.

Considering that HDAC3 is a negative regulator of memory formation (McQuown et al., 2011), we hypothesized that HDAC3 negatively regulates cocaine-context-associated memory formation (as tested by CPP, a model of cocaine-contextassociated memory; Cunningham et al., 2006). More specifically, we predict that cocaine exposure during the conditioning phase of CPP relieves HDAC3-mediated repression of genes necessary for the contextual association that leads to acquisition. In support of the idea that HDACs prevent strengthening of associative memories during CPP conditioning, Taniguchi et al. (2012) observed that viral overexpression of a mutant, nuclear sequestered 
form of HDAC5 in the mouse NAc suppresses cocaine-induced CPP acquisition only when transduced before CPP conditioning, but not when transduced after CPP conditioning. This suggests that HDACs function to regulate transcription during the consolidation phase of CPP acquisition. We addressed the above hypothesis using $\mathrm{Hdac}^{\text {flox/flox }}$ genetically modified adult mice (Mullican et al., 2011) treated with adeno-associated virus expressing Cre recombinase (AAV-Cre) to generate NAc-specific deletions of Hdac3 and examine the effect on histone acetylation, gene expression, and cocaineinduced CPP.

\section{Materials and Methods}

Subjects and surgical procedures

All experiments were performed in accordance with the institutional animal care and use committee at the University of California, Irvine, and were consistent with Federal guidelines. Mice of either sex were 8-12 weeks old and had access to food and water ad libitum in their home cages with lights maintained on a $12 \mathrm{~h}$ light/dark cycle. Behavioral testing was performed during the light portion of the cycle. $H d a c 3^{\text {flox/flox }}$ and wild-type $\left(\mathrm{Hdac}^{+/+}\right)$littermate mice were maintained on a C57BL/6 background (Mullican et al., 2011). Briefly, these mice were generated at the laboratory of Dr. Mitch Lazar at the University of Pennsylvania (Philadelphia, PA) with loxP sites flanking exon 4 through exon 7 of the Hdac3 gene, a region required for the catalytic activity of the enzyme. NAc-specific Hdac3 deletions were generated 2 weeks before behavioral testing by infusing $0.25 \mu \mathrm{l}\left(\sim 1 \mathrm{E}^{13}\right.$ vector particles, titer and quality quantified by Penn Vector Core, University of Pennsylvania) of AAV2.1-Cre (AAV-Cre; Penn Vector Core) at a rate of $0.1 \mu \mathrm{l} / \mathrm{min}$ bilaterally into the NAc $(\mathrm{A} / \mathrm{P}+1.2 \mathrm{~mm} ; \mathrm{M} / \mathrm{L}+1.0$ $\mathrm{mm} ; \mathrm{D} / \mathrm{V}-4.2 \mathrm{~mm})$ of $\mathrm{Hdac} 3^{\text {flox/flox }}$ and $\mathrm{Hdac}^{+/+}$mice, anesthetized with isofluorane in a digital stereotaxis (Stoelting).

\section{Immunohistochemistry}

To verify Hdac3 deletions after CPP testing, all mice were deeply anesthetized with $0.1 \mathrm{ml}$ of sodium pentobarbital injected intraperitoneally (50 mg/kg; Sigma-Aldrich) and perfused transcardially with ice-cold PBS (PBS, pH 7.4; Sigma-Aldrich) followed by ice-cold $4 \%$ paraformaldehyde ( $\mathrm{pH}$ 7.4; Fisher Scientific) using a peristaltic perfusion pump (Fisher Scientific). Whole brain specimens were harvested and placed in $4 \%$ paraformaldehyde solution at $4^{\circ} \mathrm{C}$ overnight followed by incubation in $30 \%$ sucrose-ddH2O solution (Fisher Scientific) for $48 \mathrm{~h}$ at $4^{\circ} \mathrm{C}$ before sectioning. Brains were embedded in Tissue-Tek OCT (Sakura FineTek) and sectioned at $-20^{\circ} \mathrm{C}$. Serial coronal sections $20 \mu \mathrm{m}$ thick were cut on a Cryostat and collected from the region corresponding to the NAc. In all sections, DAPI staining was performed to visualize nuclei. Immunohistochemistry (IHC) was performed with anti-HDAC3 IgG (1:1000; Cell Signaling Technology; Fig. 1A) primary antibody and goat anti-rabbit FITC secondary (Jackson ImmunoResearch). Images were acquired using an Olympus BX51 microscope with a $4 \times$ or $20 \times$ objective, CCD camera (QImaging), and QCapture Pro 6.0 software (QImaging). Confocal raster scan images were acquired with Zeiss Axiovert 200M inverted microscope using a $20 \times$ apochromatic objective using the Slide Scan module of MetaMorph (Molecular Devices). ImageJ software was used to quantify optical densities of target proteins in both hemispheres of at least three slices per animal to give a mean optical density \pm SEM for that animal.
Coronal sections from a separate set of mice (those used in the quantitative RT-PCR [RT-qPCR] studies, see below) were used to examine H4K8Ac levels by IHC with anti-H4K8Ac IgG (1:1000; Abcam; Fig. 3B). Those slices came from flash-frozen brains of mice killed $1 \mathrm{~h}$ after drug injection and $30 \mathrm{~min}$ after conditioning (see below). The $20-\mu \mathrm{m}$-thick coronal sections were thaw mounted on glass slides, fixed with $4 \%$ paraformaldehyde for $10 \mathrm{~min}$ at room temperature, and subjected to IHC as described above.

\section{$C P P$}

Cocaine-induced CPP was performed as described previously (Malvaez et al., 2010). Briefly, mice were handled for $2 \mathrm{~min} / \mathrm{d}$ for $3 \mathrm{~d}$ before the pretest. The next day, they were paired $30 \mathrm{~min} / \mathrm{d}$ for $4 \mathrm{~d}$ (unbiased, counterbalanced protocol) with alternating intraperitoneal injections of cocaine- $\mathrm{HCl}(2.5,5$, or $10 \mathrm{mg} / \mathrm{kg}$; Sigma-Aldrich $)$ and $0.9 \%$ saline. Fortyeight hours after the last conditioning session, preference (difference in time spent in the cocaine-paired compartment compared with the salinepaired compartment [CPP score]) was assessed (15 min test) in all animals in a drug-free state. Preference and total distance traveled (to rule out behavioral changes in motility as a confounding factor) were tracked with MPEG videos recorded with digital video cameras mounted above the CPP chambers using EthoVision 3.1 software (Noldus Technology).

\section{Chromatin immunoprecipitation and $R T-q P C R$}

$H d a c 3^{\text {flox/flox }}, \mathrm{Hdac}^{+/+}$, and C57BL/6 mice were handled, administered the pretest, and given either $5 \mathrm{mg} / \mathrm{kg}$ cocaine or saline in a paired compartment as described above for CPP. One hour after that injection (and 30 min after the end of the conditioning session), mice were killed by cervical dislocation and the brains were flash frozen by submersion into dry, ice-cold isopentane and stored at $-80^{\circ} \mathrm{C}$. In the case of $\mathrm{C} 57 \mathrm{BL} / 6$ tissue, the same brains were used for RT-qPCR and chromatin immuno- 
precipitation (ChIP) by collecting punches from one hemisphere for PCR and the other for ChIP in a counterbalanced fashion.

$R T-q P C R$. Tissue was collected as $2 \times 500 \mu \mathrm{m}^{3}$ punches from coronal sections in the area of the focal deletion in $\mathrm{Hdac}^{\text {flox/flox }}$ and comparable area in $\mathrm{Hdac} 3^{+/+}$mice as confirmed by IHC from adjacent $20 \mu \mathrm{m}$ coronal sections (see above). RNA was isolated using the RNeasy Minikit (Qiagen). cDNA was made from $50 \mathrm{ng}$ of total RNA using the Transcriptor First Strand cDNA Synthesis kit (Roche Applied Science). The following primers were derived from the Roche Universal ProbeLibrary: c-Fos mRNA left primer, $5^{\prime}$-ggggcaaagtagagcagcta- $3^{\prime}$; $c$-Fos mRNA right primer, $5^{\prime}$-agctccctcctccgattc- $3^{\prime}$; probe, atggctgc; $N r 4 a 2$ left primer, $5^{\prime}$ ttgcagaatatgaacatcgaca- $3^{\prime} ; \mathrm{Nr} 4 a 2$ right primer, $5^{\prime}$-gttccttgagcccgtgtct- $3^{\prime}$; probe, ttctcctg; Grin $3 a$ left primer, $5^{\prime}$-ggtttcacagagcattaaacacat- $3^{\prime}$; Grin 3 a right primer, $5^{\prime}$-ggtccatcttctccatctgc- $3^{\prime}$; probe, gcagccat; Egr 2 left primer, $5^{\prime}$-ctacccggtggaagacctc- $3^{\prime}$; Egr 2 right primer, $5^{\prime}$-gtcaatgttgatcatgccatct- $3^{\prime}$; probe, cttcccca; Hdac4 left primer, $5^{\prime}$-aatcctgcccgtgtgaac- $3^{\prime}$; Hdac4 right primer, 5' -gtaggggccacttgcaga-3'; probe, gcccagca; Hdac5 left primer, $5^{\prime}$-ccacggactcctctgcat-3'; Hdac5 right primer, $5^{\prime}$-ctggggctacctccacct- $3^{\prime}$; probe, caggagcc; Atf 3 left primer, $5^{\prime}$-gacagagtgcctgcacaaag3'; Atf3 right primer, $5^{\prime}$-catgtatatcaaatgctgttt-3'; probe 17 of Roche Universal Library (c-Fos, Nr4a2, Grin3a, Egr2, Hdac4, Hdac5, and Atf3 mRNA probes are conjugated to the dye FAM); glyceraldehyde-3phosphate dehydrogenase (Gapd) mRNA left primer, $5^{\prime}$-atggtgaaggtcggtgtga-3'; Gapd mRNA right primer, 5' -aatctccactttgccactgc-3'; probe, tggcggtattgg (Gapd mRNA probe is conjugated to LightCycler Yellow 555). The nonoverlapping dyes and quencher on the reference gene allow for multiplexing in the Roche LightCycle 480 II machine. All values were normalized to Gapd expression levels. Analysis and statistics were performed using the Roche proprietary algorithms and REST 2009 software based on the Pfaffl method (Pfaffl, 2001; Pfaffl et al., 2002).

ChIP. C57BL/6 mice were injected with either $5 \mathrm{mg} / \mathrm{kg}$ cocaine or saline and confined for $30 \mathrm{~min}$ (as described above for RT-qPCR and $\mathrm{CPP}$ ). Brains were collected $1 \mathrm{~h}$ after the drug injection and the NAc isolated from $2 \times 500 \mu \mathrm{m}^{3}$ punches taken from coronal sections containing the NAc from the contralateral hemisphere used in RT-qPCR from the same mouse. Coronal sections adjacent to the punches from the same animals were used for H4K8Ac IHC (as stated above). ChIP was performed as described previously (Malvaez et al., 2011) with a kit from Millipore. Briefly, tissue was cross-linked using $1 \%$ formaldehyde (Sigma-Aldrich), lysed, and sonicated, and chromatin was immunoprecipitated overnight with anti-HDAC3 IgG (Millipore), anti-acetylated H4 lysine 8 IgG (anti-H4K8Ac; Millipore), or anti-rabbit IgG (negative control; Millipore). The immunoprecipitate was collected using magnetic protein A beads (Millipore). After washing, chromatin was eluted from the beads and reverse cross-linked in the presence of proteinase $\mathrm{K}$ before column purification of DNA. Fos and Nr4a2 promoter enrichment in ChIP samples was measured by quantitative real-time PCR using the Roche 480 LightCycler and SYBR Green. Primer sequences for the promoters, designed by the Primer 3 program, were as follows: Fos left primer, 5' -tacgacccettcaggcatac- $3^{\prime}$; Fos right primer, $5^{\prime}$-gttttaaaggacggcagcac- $3^{\prime}$; Nr4a2 left primer $5^{\prime}$-cgggacaactgtctccactt- $3^{\prime}$; Nr4a2 right primer, $5^{\prime}$-catgtatatcaaatgctgttt- $3^{\prime}$. Five microliters of input, antiHDAC3 IgG, anti-H4K8Ac IgG, or anti-rabbit IgG immunoprecipitate from four separate mice from each condition were examined in duplicate. Percentage input was calculated for both the ChIP and IgG samples and then the fold enrichment was calculated as a ratio of the ChIP to IgG. An in-plate standard curve determined amplification efficiency (AE). The equation used was $\mathrm{AE}^{\wedge}{ }^{(\text {Input } \mathrm{Ct}-\mathrm{ChIP} \mathrm{Ct})} / \mathrm{AE}^{\wedge}{ }^{\text {(Input } \mathrm{Ct}-\mathrm{IgGCt})} . \mathrm{Sam}-$ ples were then normalized to the saline condition.

\section{Western blot analysis}

C57BL/6 mice were injected with either $5 \mathrm{mg} / \mathrm{kg}$ cocaine or saline and confined for $30 \mathrm{~min}$ (as described above for RT-qPCR, CPP, and ChIP). Brains were collected $1 \mathrm{~h}$ after the drug injection and the NAc isolated from $1 \mathrm{~mm}$ coronal sections. Protein was isolated by homogenization on ice in tissue protein extraction reagent (T-PER; Thermo Scientific) in the presence of protease and phosphatase inhibitors. The final protein concentration was determined using the Bio-Rad protein assay and bovine serum albumin standards. Tissue samples were prepared in a standard
$5 \times$ SDS/PAGE sample buffer ( 1 м Tris, pH $6.8,20 \%$ v/v glycerol, $10 \%$ w/v SDS, $0.05 \%$ bromophenol blue, and $10 \mathrm{~mm} 2-\beta$-mercapto-ethanol). Ten micrograms of protein was loaded per well and run at $120 \mathrm{~V}$ for $1 \mathrm{~h}$ on NuPage $10 \%$ Bis-Tris polyacrylamide gels (Invitrogen). Electrophoretic transfer was then performed overnight at $30 \mathrm{~V}$ onto a polyvinylidene difluoride membrane. Membranes were blocked for $2 \mathrm{~h}$ at room temperature in blocking solution ( $5 \%$ nonfat milk/Tris-buffered saline with Tween 20) and then incubated in primary antibodies (1:10,000 rabbit anti-HDAC3; Millipore; 1:10,000 rabbit anti-GAPDH; Millipore) with agitation overnight at $4^{\circ} \mathrm{C}$. Membranes were then rinsed three times for 10 min each in blocking solution with agitation. Next, membranes were incubated for $1 \mathrm{~h}$ at room temperature in a 1:10,000 dilution of polyclonal goat anti-rabbit HRP secondary antibody (Millipore). Membranes were then rinsed three times for $10 \mathrm{~min}$ each in TBS with agitation. Supersignal Westpico Chemiluminescent substrate (Thermo Scientific) was used for chemiluminescent detection according to the manufacturer's instructions and analyzed using ImageJ software.

\section{Statistics}

Two-way ANOVAs followed by Bonferroni's post hoc tests (Prizm) were used to make specific comparisons when significant interactions were observed with $\alpha$ levels held at 0.05 . Specific group comparisons were analyzed by Student's $t$ tests $(\alpha=0.05)$. Data are reported as mean \pm SEM.

\section{Results}

\section{Site-specific and homozygous Hdac3 gene deletion in the adult mouse NAc}

In this study, NAc-specific, homozygous deletions of Hdac3 were generated in adult mice to investigate the in vivo function of HDAC3 at the molecular and behavioral levels during CPP. This method allowed us to avoid developmental and other confounds associated with traditional knock-out mice. In addition, because HDAC3 is expressed in neurons, oligodendrocytes, and glia (Broide et al., 2007; Baltan et al., 2011), the use of AAV serotype 2.1, which preferentially transduces neurons (Burger et al., 2004), allowed us to delete $H d a c 3$ specifically in neurons. We have previously used AAV-Cre to generate focal deletions of CREBbinding protein in the mouse NAc (Malvaez et al., 2011). The same method was used to generate site-specific deletions of Hdac3 in the NAc (Fig. 1). Figure 1A shows HDAC3 expression in $4 \times$ (the NAc core is boxed in white) and $20 \times$ (magnification of the boxed region) representative images of coronal slices from intra-NAc AAV-Cre infused $\mathrm{Hdac}^{+/+}$(top) and $\mathrm{Hdac}^{\text {flox/flox }}$ (bottom) mice after IHC with anti-HDAC3 antibody. DAPI staining (right) confirmed the presence of nuclei in the NAc of both genotypes. Quantified HDAC3 immunoreactivity in the NAc of all $\mathrm{Hdac}^{+/+}$and $\mathrm{Hdac} 3^{\text {flox/flox }}$ mice used in this study is shown in Figure $1 B$. HDAC3 immunoreactivity was significantly reduced in the NAc of $H d a c 3^{\text {flox/flox }}$ mice compared with $\mathrm{Hdac}^{+/+}$(mean percentage of $\mathrm{Hdac}^{+/+} \pm \mathrm{SEM}: \mathrm{Hdac}^{+/+}=$ $100 \pm 16.972, n=39 ;$ Hdac3 $^{\text {flox/flox }}=10.678 \pm 2.561, n=40$, $\left.t_{(79)}=5.174,{ }^{\star} p<0.001\right)$.

The extent of HDAC3 deletion in $H d a c 3^{\text {flox } / \text { flox }}$ mice is shown in Figure $1 C(n=40$ mice). In this study, viral infusions and focal deletions were bilateral and $H$ dac 3 deletions were restricted to the NAc core and shell regions in all $\mathrm{Hdac} 3^{\text {flox/flox }}$ mice included in the data presented in subsequent figures. However, the figure shows only one hemisphere shaded so that the anatomical designations remain legible. These data confirm that NAc-specific Hdac3 deletions can be generated in adult mice by intra-NAc infusions of AAV-Cre. 
A

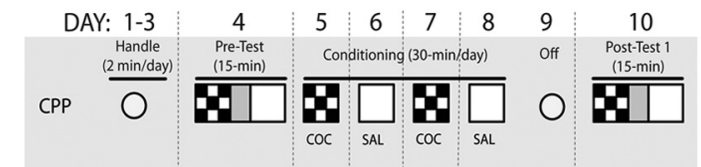

B
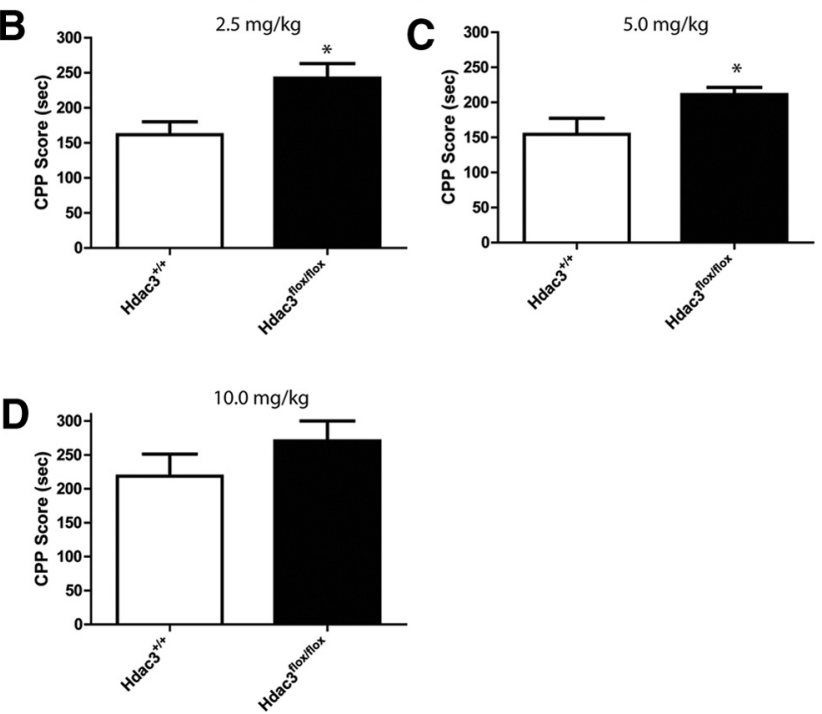

Figure 2. Cocaine-induced CPP acquisition is enhanced in $H d a c 3^{\text {flox/flox }}$ mice compared with $\mathrm{Hdac}^{+/+}$at low doses of cocaine. $\boldsymbol{A}$, Schematic of the CPP procedure (fully described in Materials and Methods). B, C, In Hdac ${ }^{\text {flox/flox }}$ mice infused intra-NAc with AAV-Cre, CPP acquisition is significantly enhanced after conditioning with 2.5 or $5 \mathrm{mg} / \mathrm{kg}$ cocaine compared with intra-NACAAV-Cre infused Hdac $3^{+/+}$littermates. For $2.5 \mathrm{mg} / \mathrm{kg}$ experiment: $\mathrm{Hdac}^{+/+}, n=$

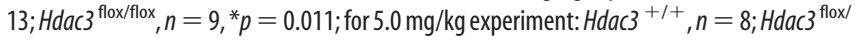
flox, $n=9,{ }^{*} p=0.032$. $\boldsymbol{D}$, At a higher dose, no differences were seen between genotypes. For the $10 \mathrm{mg} / \mathrm{kg}$ experiment: $\mathrm{Hdac}^{+/+}, n=8 ; \mathrm{Hdac}^{\text {flox/flox }}, n=8 ; p=0.688$. $^{*} p<0.05$.

\section{Focal Hdac3 deletion in the mouse NAc facilitates CPP acquisition}

To investigate our hypothesis that HDAC3 is involved in the formation of cocaine-context-associated memories, $\mathrm{Hdac}^{+/+}$and $\mathrm{Hdac} 3^{\text {flox/flox }}$ mice were subjected to cocaineinduced CPP to examine the effect of NAc-specific Hdac3 deletion on acquisition/consolidation.

The schematic of the CPP procedure is shown in Figure $2 \mathrm{~A}$ (fully described in Materials and Methods). In Figure $2 B, C$, the data show that $H d a c 3^{\text {flox/flox }}$ mice exhibited enhanced CPP acquisition compared with $H d a c 3^{+/+}$mice after conditioning with low doses of cocaine (2.5 and $5.0 \mathrm{mg} / \mathrm{kg}$ cocaine, respectively), but not a higher dose $(10 \mathrm{mg} / \mathrm{kg}$; Fig. $2 D$; for $2.5 \mathrm{mg} / \mathrm{kg}$ experiment: Hdac3 $^{+1+}, n=13 ;$ Hdac3 $^{\text {flox/flox }}, n=9 ; t_{(19)}=2.820{ }^{*} p=0.011$; for $5.0 \mathrm{mg} / \mathrm{kg}$ experiment: $\mathrm{Hdac}^{+/+}, n=8 ; \mathrm{Hdac}^{\text {flox } / \text { flox }}, n=9$; $\left.t_{(15)}=2.362,{ }^{\star} p=0.032\right)$. The enhanced CPP scores in Hdac $3^{\text {flox/flox }}$ mice were similar to acquisition scores seen in both genotypes after conditioning with the higher dose of $10 \mathrm{mg} / \mathrm{kg}$ cocaine (for $10 \mathrm{mg} / \mathrm{kg}$ experiment: Hdac ${ }^{+/+}, n=8$; Hdac3 ${ }^{\text {flox/flox }}$, $\left.n=8 ; t_{(14)}=0.409, p=0.688\right)$. Hdac3 $^{\text {flox } / \text { flox }}$ mice exhibited ceiling levels of CPP acquisition after conditioning with low doses of cocaine ( 2.5 and $5 \mathrm{mg} / \mathrm{kg}$ ). When the data were analyzed by factorial ANOVA (treatment $\times$ genotype), a significant effect of genotype was observed $\left(F_{(1,48)}=10.84,{ }^{\star} p=0.012\right)$. The effect of treatment approached significance $\left(F_{(2,48)}=9.20, p=0.0641\right)$. The facilitated acquisition in $H d a c 3^{\text {flox/flox }}$ mice was most likely not due to potential performance confounds because there were no observed differences in distance traveled in a 15 min posttest $\left(\right.$ mean \pm SEM: Hdac $^{+/+}=4219.523 \pm 119.376 \mathrm{~cm}, n=29$; Hdac3 $^{\text {flox/flox }}=4119.422 \pm 102.439 \mathrm{~cm}, n=26 ; t_{(53)}=0.6292$,

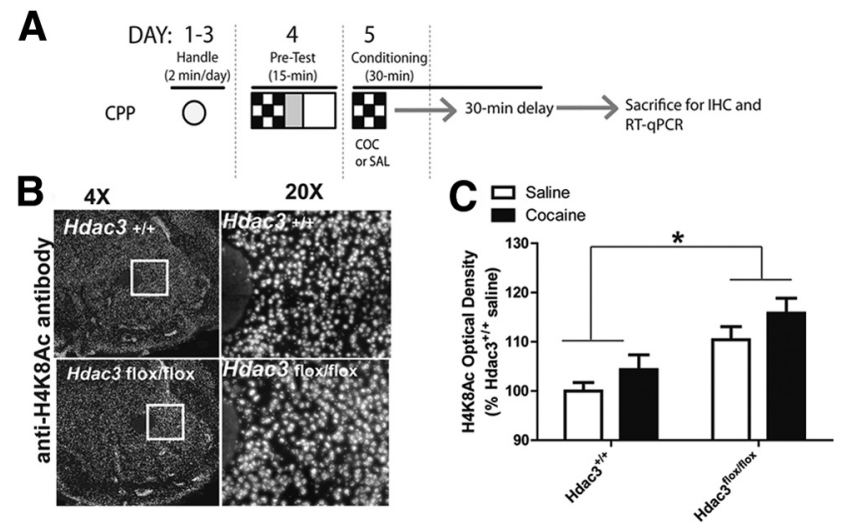

Figure 3. Acetylated $\mathrm{H} 4 \mathrm{~K} 8$, a marker of transcriptional activation, is augmented in the NAC after $\mathrm{Hdac} 3$ deletion and CPP conditioning. $\boldsymbol{A}$, In this figure, data were collected from mice killed after either saline or $5 \mathrm{mg} / \mathrm{kg}$ cocaine conditioning in a single CPP trial. A schematic of the experimental design illustrates how this was done (fully described in Materials and Methods). $\boldsymbol{B}$, Representative $4 \times$ and $20 \times$ magnified images of cocaine-treated $\mathrm{HdaC} 3^{+/+}$(top) and $\mathrm{HdaC}^{\text {flox/flox }}$ (bottom) coronal hemisections immunostained with anti-H4K8Ac lgG illustrate an overall increase of H4K8Ac in the NAc after Hdac3 deletion. C, Quantification of anti-H4K8AC IHC demonstrates that H4K8Ac is more abundant in $H d a c 3^{\text {flox/flox }}$ mice compared with Hdac $^{+/+}$littermates. Hdac $3^{\text {flox } / \text { flox }}$ : saline, $n=6$; cocaine, $n=8 ; H_{d a c}{ }^{+/+}:$saline, $n=5$; cocaine, $n=5 ; p=0.024 .{ }^{*} p<0.05$.

$p=0.532$ ). These data show that NAc-specific Hdac3 deletion enhances cocaine-induced CPP acquisition.

NAc-specific Hdac3 deletion enhances global levels of $\mathrm{H} 4 \mathrm{~K} 8 \mathrm{Ac}$ in $\mathrm{Hdac} 3^{\text {flox/flox }}$ mice concomitant with increases in c-Fos, Nr4a2, and Grin3a mRNA levels

To examine the molecular effects of $\mathrm{Hdac} 3$ deletion, we examined histone acetylation and gene expression during the consolidation phase of cocaine-context-associated memory formation. Consolidation is the phase of memory during which gene expression is necessary for the encoding of a learning event into long-term memory (McGaugh, 2000). Therefore, this is the optimum time to examine molecular effects of $\mathrm{Hdac} 3$ deletion that would ultimately correlate with changes in behavior observed in long-term memory tests after conditioning.

In the mouse hippocampus, an in vivo molecular substrate of HDAC3 is H4K8Ac (McQuown et al., 2011), which is also a marker of transcriptional activation (Kouzarides, 2007). We hypothesized that during the consolidation window in the NAc, $\mathrm{H} 4 \mathrm{~K} 8 \mathrm{Ac}$ is likewise a target of HDAC3 deacetylation. To test this, a separate set of AAV-Cre infused $\mathrm{Hdac}^{+/+}$and $\mathrm{Hdac} 3^{\text {flox/flox }}$ mice were killed $1 \mathrm{~h}$ after the first cocaine $(5 \mathrm{mg} / \mathrm{kg}$ ) pairing (or saline administration) to investigate HDAC3-mediated, cocaineinduced histone acetylation and gene expression during longterm associative memory formation in the CPP task (Fig. $3 A$; described in the Materials and Methods).

HDAC3-mediated histone acetylation was examined by IHC with anti-H4K8Ac antibodies (Fig. 3B) and quantified (Fig. 3C) in NAc-containing coronal slices of $\mathrm{Hdac}^{+/+}$and $\mathrm{Hdac} 3^{\text {flox/fox }}$ mice with confirmed HDAC3 deletion from adjacent serial sections. The same brains were used to examine $c$-Fos, Nr4a2, and other mRNA levels shown in Figure 4 by taking $2 \times 500 \mu \mathrm{m}^{3} \mathrm{NAc}$ punches (used in RT-qPCR) from the area of focal deletion identified by IHC. H4K8Ac optical density was significantly enhanced in the NAc of $\mathrm{Hdac} 3^{\text {flox/flox }}$ vs $\mathrm{Hdac} 3^{+/+}$mice (ANOVA, significant effect of genotype, $F_{(1,14)}=6.41,{ }^{*} p=0.024$; Hdac $3^{\text {flox } / \text { flox }}$ : saline $n=6$ mice, cocaine $n=8$ mice; $\mathrm{Hdac}^{+/+}$: saline $n=5$ mice, cocaine $n=5$ mice; Hdac3 $3^{\text {flox/flox }}$ vs Hdac3 $\left.{ }^{+/+}, p<0.05\right)$. 

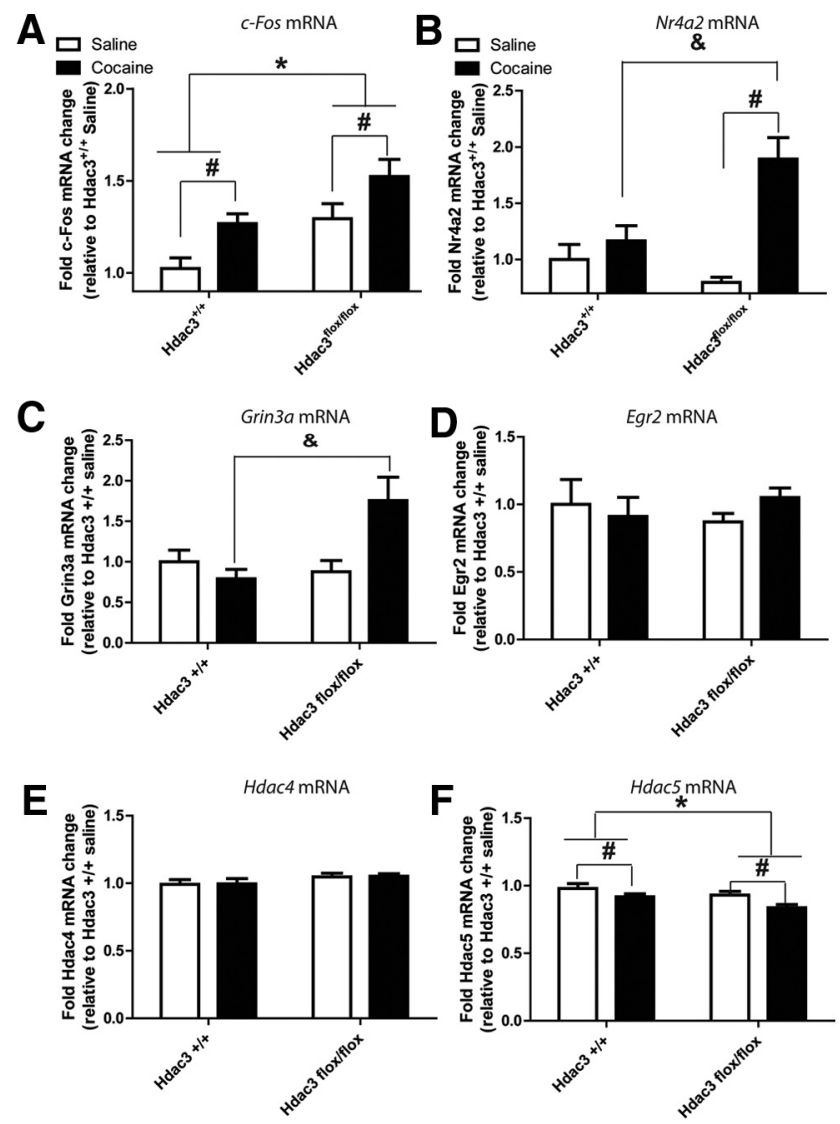

Figure 4. Changes in cocaine- and learning- and memory-associated mRNA abundances in the NAc concomitant with increased H4K8AC. $A$, Gene expression was analyzed from tissue punches collected from the NAC of the same brains shown in Figure $3 B$ in the area of focal deletion as confirmed by IHC. C-Fos mRNA was increased in both genotypes after CPP conditioning with $5 \mathrm{mg} / \mathrm{kg}$ cocaine relative to conditioning with saline. A significant effect of genotype was also found by two-way ANOVA, indicating that more c-Fos mRNA was present in the NAc of $H d a c 3^{\text {flox/flox }}$ mice relative to $H d a c 3^{+/+}$littermates. $H d a c 3^{\text {flox/flox }}$ : saline, $n=6$; cocaine, $n=$ 8 ; Hdac $3^{+/+}$: saline, $n=5$; cocaine, $n=5$. ${ }^{*}$ Significantly different from $\mathrm{Hdac}^{+/+}, p<$ 0.05. " significantly different from saline, $p<0.05$. $B, N r 4 a 2$ mRNA levels from the same tissue punches used in Figure $4 B$ were significantly enhanced in cocaine-conditioned, but not salineconditioned, $\mathrm{Hdac} 3^{\text {flox/flox }}$ mice relative to $\mathrm{Hdac} 3^{+/+}$littermates. There was a significant interaction between treatment and genotype affecting Nr4a2 mRNA abundance in the NAc. HdaC $^{\text {flox/flox: }}$ saline, $n=6$; cocaine, $n=8$; $\operatorname{Hdac}^{+/+}$: saline, $n=5$; cocaine, $n=5$. "Significantly different from saline, $p<0.05$. \&Significantly different from cocaineconditioned $\mathrm{Hdac} 3^{+/+}, p<0.05$. C, Grin3a mRNA levels from the same tissue punches were likewise significantly enhanced in cocaine-conditioned, but not saline-conditioned, $H d a c 3^{\text {flox/flox }}$ mice relative to $H d a c 3^{+/+}$littermates. Hdac $3^{\text {flox/flox }}$ : saline, $n=6$; c0caine, $n=8 ; \mathrm{HdaC}^{+/+}$: saline, $n=5$; cocaine, $n=5$. \& Significantly different from cocaine-conditioned Hdac3 ${ }^{+1+}, p=0.039 . \boldsymbol{D}, \boldsymbol{E}$, Egr2 and Hdac4 mRNA levels remained unchanged by treatment or genotype. $H_{d a c} 3^{\text {flox/flox: }}$ saline, $n=6$; cocaine, $n=8$; Hdac $3^{+/+}$: saline, $n=5$; cocaine, $n=5$. $F$, Hdac 5 mRNA is decreased in both genotypes after CPP conditioning with cocaine relative to conditioning with saline. A significant effect of genotype is also observed, indicating that less $\mathrm{Hdac} 5 \mathrm{mRNA}$ is present in the NAC of $\mathrm{HdaC} 3^{\text {flox/flox }}$ mice relative to $\mathrm{Hdac} 3^{+/+}$littermates. $\mathrm{Hdac} 3^{\text {flox/flox }}$ : saline, $n=6$ mice; cocaine, $n=8$ mice; $H_{d a c} 3^{+1+}:$ saline, $n=5$; cocaine, $n=5$. *Significantly different from $\mathrm{HdaC} 3^{+1+}, p<0.05$. "Significantly different from saline, $p<0.05$.

No effect of treatment was observed $\left(F_{(1,14)}=1.465, p=0.2461\right)$. Therefore, histone $\mathrm{H} 4$ lysine 8 (H4K8) was more acetylated in the NAc of mice with Hdac3 deletions. Outside of the region of deletion, in the dorsal striatum, H4K8Ac levels did not differ between groups, as determined by ANOVA (effect of genotype, $F_{(1,20)}=$ $0.12, p=0.868$; effect of treatment, $F_{(1,20)}=3.63, p=0.360$; Hdac $^{\text {flox/flox }}$ : saline $n=6$ mice, cocaine $n=8$ mice; Hac $^{+/+}$: saline $n=5$ mice, cocaine $n=5$ mice).
In NAc punches taken from within the region of HDAC3 deletion, $5 \mathrm{mg} / \mathrm{kg}$ cocaine-induced Fos gene expression was examined by RT-qPCR. In both genotypes, $c$-Fos mRNA is significantly enhanced after cocaine administration and a single CPP conditioning trial (Fig. $4 A$; ANOVA, significant effect of cocaine treatment $F_{(1,56)}=12.12,{ }^{\star} p=0.003 ; \mathrm{Hdac}^{\text {flox/flox}}$ : saline $n=6$ mice, cocaine $n=8$ mice; $\operatorname{Hdac}^{+/+}$: saline $n=5$, cocaine $n=5$; $\left.H d a c 3^{\text {flox/flox }}>\mathrm{Hdac}^{+/+}, p<0.05\right)$. There is also a significant effect of genotype on $c$-Fos mRNA levels (ANOVA, $F_{(1,56)}=$ 15.07, $p=0.001$; Hdac $\left.3^{\text {flox/flox }}>\mathrm{Hdac}^{+/+}, p<0.05\right)$. These data demonstrate that cocaine conditioning enhances $c$-Fos mRNA abundance in both genotypes compared with saline conditioning and that $\mathrm{Hdac} 3$ deletion results in an overall enhancement of $c$-Fos mRNA in $\mathrm{Hdac} 3^{\text {flox/flox }}$ vs $\mathrm{Hdac}^{+/+}$mice.

In the same NAc punches used to investigate Fos expression, $\mathrm{Nr} 4 a 2$ mRNA abundance was also found to be increased after 5 $\mathrm{mg} / \mathrm{kg}$ cocaine administration and a single CPP conditioning trial (Fig. $4 B$ ). In the case of $N r 4 a 2$, however, cocaine enhanced mRNA expression only in $\mathrm{Hdac} 3^{\text {flox/flox }}$ mice treated with cocaine, but not in cocaine-treated $\mathrm{Hdac} 3^{+/+}$littermates (ANOVA, significant effect of treatment $F_{(1,38)}=22.31, p<0.001$; Hdac $3^{\text {flox/flox }}$ : saline $n=6$ mice, cocaine $n=8$ mice; $H$ dac $3^{+/+}$: saline $n=5$, cocaine $n=5 ;$ Hdac $^{\text {flox } / \text { flox }}$ saline $<$ Hdac $3^{\text {flox } / \text { flox }}$ cocaine, $p<0.001$; Hdac $3^{+/+}$saline vs $H$ dac $^{+/+}$cocaine, $p=$ n.s.). Although a trend was observed for the effect of genotype on Nr4a2 mRNA abundance (ANOVA, effect of genotype, $\left.F_{(1,38)}=3.86, p=0.10\right)$, there was a significant interaction between genotype and treatment (ANOVA, significant interaction $F_{(1,38)}=12.15, p=0.005 ; H_{d a c 3}{ }^{\text {flox/flox }}>\mathrm{Hdac}^{+/+}$, $p<0.05)$. These data strongly suggest that in the NAc, cocaine-mediated Nr4a2 mRNA expression is regulated by HDAC3 during CPP conditioning.

In those same NAc punches, the mRNA levels of other genes implicated in cocaine-induced neuroplasticity were also examined; namely Grin3a (Fig. 4C), Egr2 (Fig. 4D), Atf3 (data not shown), Hdac4 (Fig. 4E), and Hdac5 (Fig. 4F). Grin3a mRNA encodes an NMDA receptor subunit shown to be important for learning and memory and synaptic plasticity mechanisms (Larsen et al., 2011). Although Grin3a itself has not been examined with regard to cocaine-induced neuroplasticity, Grin $3 a$ mRNA expression is significantly reduced in the human peripheral blood lymphocytes of opioid addicts (Roozafzoon et al., 2010). Furthermore, NMDA receptors play a critical role in the consolidation of cocaine-context-associated memories (Alaghband and Marshall, 2012; Carmack et al., 2013). Like Nr4a2 mRNA, cocaine enhanced Grin $3 a$ mRNA expression only in $H d a c 3^{\text {flox/flox }}$ mice treated with cocaine, but not in cocainetreated $\mathrm{Hdac}^{+/+}$littermates (Fig. 4C; ANOVA, significant interaction between genotype and treatment, $F_{(1,17)}=18.03$, $p=0.029 ;$ Hdac $^{\text {flox } / \text { flox }}$ : saline $n=6$ mice, cocaine $n=8$ mice; Hdac $3^{+/+}$: saline $n=5$, cocaine $n=5$ ). Although a trend was observed for the effect of treatment on Grin $3 a$ mRNA abundance (ANOVA, effect of treatment, $F_{(1,17)}=10.81, p=0.083$ ), there was no effect of genotype $\left(F_{(1,17)}=6.80, p=0.1622\right)$. These data suggest that in the NAc, cocaine-mediated Grin3a mRNA expression is regulated by $\mathrm{HDAC} 3$, and possibly $\mathrm{H} 4 \mathrm{~K} 8 \mathrm{Ac}$, during $\mathrm{CPP}$ conditioning.

After conditioning with either saline or cocaine, no significant effects were observed by ANOVA between treatment or genotype groups for Egr2 (Fig. 4D). Egr2, like Fos, is an immediate early gene involved in cocaine-induced neuroplasticity (Freeman et al., 2010). Atf3 mRNA is translated into a CREB superfamily transcription factor regulated by psychostimulant administration 
and is implicated in drug-induced neuroplasticity (Green et al., 2008). In this study, Atf3 mRNA (data not shown) was significantly less abundant after conditioning with cocaine in both genotypes (ANOVA, effect of treatment $F_{(1,20)}=$ $\left.20.08,{ }^{\star} p=0.036\right)$. No effect of genotype was observed (ANOVA, effect of genotype $\left.F_{(1,20)}=0.00,{ }^{\star} p=0.978\right)$.

Although Hdac4 mRNA remained unchanged in all of the groups tested (Fig. $4 E$ ), a significant effect of genotype and treatment, but no interaction, was observed for Hdac5 mRNA (Fig. 4F; ANOVA, significant effect of genotype $F_{(1,19)}=24.12,{ }^{\star} p=0.012$; ANOVA significant effect of cocaine treatment $F_{(1,19)}=$ $16.56,{ }^{\star} p=0.032 ;$ Hdac3 $^{\text {flox/flox }}$ : saline $n=6$ mice, cocaine $n=8$ mice; $\mathrm{Hdac}^{+/+}$: saline $n=5$, cocaine $n=5$; $\left.\mathrm{Hdac}^{\text {flox/flox }}<\mathrm{Hdac3}^{+/+}, \mathrm{p}<0.05\right)$. These latter data indicate that loss of HDAC3 in the mouse NAc results in less abundance of Hdac5 mRNA after CPP conditioning with either saline or cocaine.

A single CPP conditioning trial with cocaine enhanced the levels of $\mathrm{H} 4 \mathrm{~K} 8 \mathrm{Ac}$ at the Fos and Nr4a2 promoters in the NAc, which was associated with a decrease in HDAC3 association with the Fos and $\mathrm{Nr} 4 \mathrm{a} 2$ promoters. Although cocaine did not cause a global, NAc-wide increase in the levels of H4K8Ac after cocaine treatment in $\mathrm{Hdac} 3^{+/+}$mice (Fig. 3C), the global amount of H4K8Ac does not accurately represent the acetylation status of promoters that regulate genes involved in neuroplastic and behavioral responses to cocaine. Therefore, ChIP assays were performed to examine the levels of H4K8Ac at the Fos and Nr4a2 promoters $1 \mathrm{~h}$ after the first cocaine $(5 \mathrm{mg} / \mathrm{kg})$ or saline injection during CPP conditioning (Fig. 5A). Because there is no HDAC3 to ChIP in the Hdac $3^{\text {flox/flox }}$ mouse NAc, C57BL/6 mice were used. The C57BL/6 mice were treated with $5 \mathrm{mg} / \mathrm{kg}$ cocaine or saline in parallel and identically to the $\mathrm{Hdac}^{\text {flox/flox }}$ and $\mathrm{Hdac}^{+/+}$mice examined in the IHC and RT-qPCR studies shown in Figure 3 and Figure 4 (and illustrated in Fig. 5A).

In the NAc punches collected from saline- and $5 \mathrm{mg} / \mathrm{kg}$ cocaine-treated mice that underwent a single CPP conditioning trial, cocaine treatment significantly enhanced the amount of Fos promoter enriched by anti-H4K8Ac ChIP, indicating that there was significantly increased acetylation of $\mathrm{H} 4 \mathrm{~K} 8$ at the Fos promoter after cocaine treatment during a single CPP conditioning trial compared with saline treatment and conditioning (Fig. $5 B$, $t_{(10)}=6.174,{ }^{\star} p<0.001$; saline $n=6$ mice, cocaine $n=6$ mice).

We next examined the occupancy of HDAC3 at the Fos promoter $1 \mathrm{~h}$ after cocaine treatment and a single CPP conditioning trial. ChIP was performed with anti-HDAC3 antibodies. These

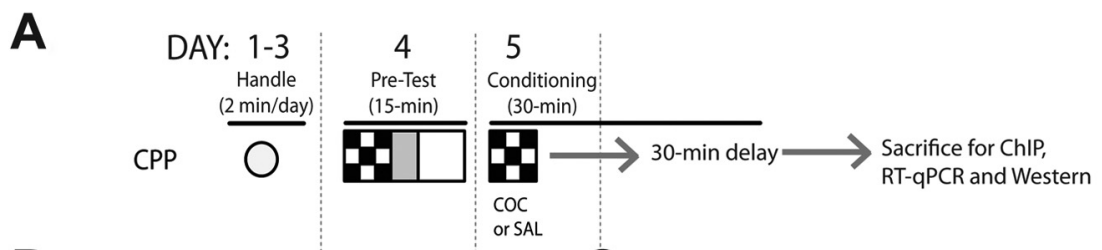

B Anti-H4K8Ac ChIP of Fos promoter

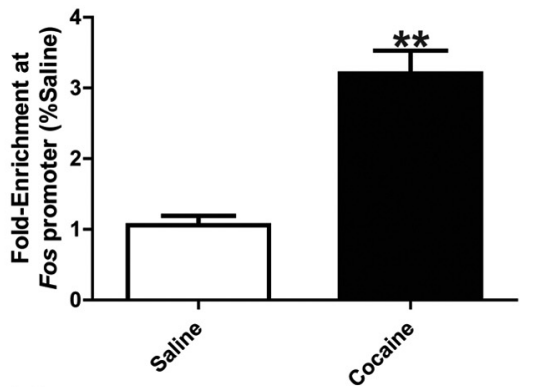

D Anti-H4K8Ac ChIP of Nr4a2 promoter
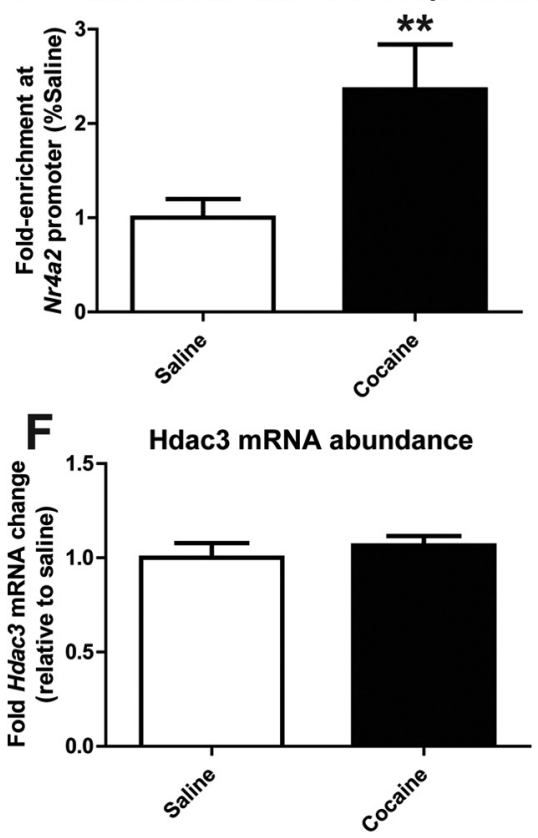

Figure 5. H4K8Ac and HDAC3 at the Fos and Nr4a2 promoters in the C57BL/6 mouse NAc are affected by conditioning with cocaine. $A$, Schematic of the experimental design illustrating how $57 \mathrm{BL} / 6$ mice were treated with $5 \mathrm{mg} / \mathrm{kg}$ cocaine or saline and killed exactly as the mice used for Figure 3 and Figure 4 (fully described in Materials and Methods). B, ChIP with anti-H4K8AC antibodies isolated significantly more Fos promoter from the NAc of cocaine-conditioned mice compared with saline-conditioned mice. ${ }^{* *} p<0.001$. C, ChIP with anti-HDAC3 antibodies isolated significantly less Fos promoter from the NAC of cocaineconditioned mice compared with saline-conditioned mice. ${ }^{*} p<0.05$. D, Anti-H4K8Ac ChIP of the Nr4a2 promoter isolated more of the promoter from the NAc of cocaine-conditioned mice compared with saline-conditioned mice. ${ }^{* *} p<0.001 . E$, Anti-HDAC3 ChIP isolated less Nr4a2 promoter from the NAc after conditioning with cocaine compared with saline. ${ }^{*} p<0.05$. For all ChIP studies: saline, $n=6$; cocaine, $n=6$. $\boldsymbol{F}$, Hdac3 mRNA levels in the NAc remained unchanged after cocaine conditioning. Saline, $n=5$; cocaine, $n=5 ; p=0.4927$. G, HDAC3 immunoreactivity from NAc proteins subjected to Western blot analyses also remains unchanged after conditioning with cocaine compared with saline. A representative image of two mice per group is shown within the graph. Saline, $n=8$; cocaine, $n=8 ; p=0.308$.

experiments were designed to address the questions of whether HDAC3 associates with the Fos promoter during conditioning and, if so, does cocaine affect that association? Using the same chromatin samples used in Figure 5B, anti-HDAC3 ChIP enriched significantly more Fos promoter DNA than IgG ChIP alone. As predicted, cocaine treatment significantly reduced the amount of Fos promoter enriched by anti-HDAC3 ChIP, indicating that much less HDAC3 was associated with the Fos promoter after cocaine treatment and a single CPP conditioning trial com- 
pared with saline treatment and conditioning (Fig. $5 C ; t_{(10)}=$ $3.62,{ }^{*} p=0.005$; saline $n=6$, cocaine $n=6$ ). These data indicate that one mechanism by which cocaine may enhance $c$-Fos mRNA expression during CPP conditioning is by relieving HDAC3mediated transcriptional repression.

Similar ChIP results were obtained from the same NAc punches when H4K8 acetylation and HDAC3 promoter occupancy were examined at the $\mathrm{Nr} 4 a 2$ promoter. CPP conditioning with $5 \mathrm{mg} / \mathrm{kg}$ cocaine significantly enhanced the amount of $N r 4 a 2$ promoter enriched by anti-H4K8Ac ChIP (Fig. $5 D ; t_{(10)}=$ $2.64,{ }^{*} p=0.039$; saline $n=6$, cocaine $n=6$ ). Furthermore, CPP conditioning with cocaine significantly reduced the amount of $N r 4 a 2$ promoter enriched by anti-HDAC3 ChIP (Fig. $5 E ; t_{(10)}=$ $3.49,{ }^{*} p=0.007$; saline $n=6$, cocaine $n=6$ ). These data indicate that significantly less HDAC3 was associated with the Nr4a2 promoter after cocaine treatment and a single CPP conditioning trial compared with saline treatment.

Finally, Hdac3 mRNA levels were examined in the same cocaine- and saline-treated C57BL/6 mice to determine whether cocaine or conditioning regulates $H d a c 3$ mRNA expression. In those mice, cocaine administration before CPP conditioning had no effect on Hdac3 mRNA abundance in the NAc relative to saline-conditioned mice (Fig. $5 F ; t_{(8)}=0.719, p=0.4927$; saline $n=5$ mice, cocaine $n=5$ mice). In a separate set of identically treated C57BL/6 mice, HDAC3 protein levels were examined by Western blot analysis after conditioning with either saline or 5 $\mathrm{mg} / \mathrm{kg}$ cocaine. As with Hdac3 mRNA abundance, HDAC3 protein levels were unchanged by CPP conditioning with $5 \mathrm{mg} / \mathrm{kg}$ cocaine compared with conditioning with saline (Fig. $5 G ; t_{(16)}=$ $1.055, p=0.3072$; saline $n=8$ mice, cocaine $n=8$ mice). Therefore, cocaine-induced changes in HDAC3 promoter occupancy and $\mathrm{H} 4 \mathrm{~K} 8$ acetylation at the Fos and $\mathrm{Nr} 4 a 2$ promoters are not due simply to a decrease in $\mathrm{Hdac} 3 \mathrm{mRNA}$ or protein levels.

\section{Discussion}

One unique aspect of this study is that HDAC3-mediated promoter acetylation and gene expression were examined during the consolidation phase of cocaine CPP conditioning, which is a temporal window within which molecular events that are required for long-term memory formation, including gene expression, occur. The data presented in this study demonstrate that HDAC3 associates with the Fos and Nr4a2 promoters in the absence of cocaine, maintaining low levels of promoter H4K8Ac, and thus suppressing transcription. When cocaine, but not saline, was administered during conditioning, HDAC3 was removed from the Fos and Nr4a2 promoters, allowing for increased H4K8 acetylation, which is correlated with increased Fos and Nr4a2 transcription. These results suggest that HDAC3 is a negative regulator of cocaine-induced gene expression during the consolidation phase of CPP conditioning.

Furthermore, the molecular studies with the $\mathrm{Hdac}^{\text {flox/flox }}$ mice, which exhibit enhanced CPP acquisition compared with Hdac $3^{+/+}$littermates, mirror the ChIP findings above. After the first CPP conditioning trial, during consolidation, the overall levels of H4K8Ac were greater in the NAc of $H d a c 3^{\text {flox/flox }}$ mice harboring $\mathrm{Hdac} 3$ deletions compared with $\mathrm{Hdac} 3^{+/+}$mice. That increased $\mathrm{H} 4 \mathrm{~K} 8 \mathrm{Ac}$ in the absence of HDAC3 is correlated with enhanced $c$-Fos mRNA expression in the NAc of Hdac $3^{\text {flox/flox }}$ mice relative to $\mathrm{Hdac} 3^{+/+}$mice. These findings suggest that HDAC3 normally deacetylates H4K8Ac and represses Fos transcription during the consolidation of CPP conditioning.

Moreover, Nr4a2 mRNA was enhanced in the NAc of $H d a c 3^{\text {flox/flox }}$ mice harboring Hdac3 deletions compared with
Hdac $3^{+/+}$mice after conditioning with cocaine, but not saline. These data indicate that HDAC3 is likely involved in cocaineinduced expression of Nr4a2. Nearly identical results were observed when Grin3a mRNA was examined. These findings suggest that repression of cocaine-activated genes in the NAc during conditioning may be one of the mechanisms by which HDAC3 suppresses CPP acquisition. This idea is supported by previous evidence showing that overexpression of HDAC4 or HDAC5 in the NAc during conditioning, but not afterward, inhibits the formation of cocaine-induced CPP (Kumar et al., 2005; Renthal et al., 2007; Taniguchi et al., 2012). Our study also suggests coordinated expression between HDAC3 and HDAC5, because NAc-specific Hdac3 deletion results in less HDAC5 expression after CPP conditioning.

C-FOS in the NAc is an immediate early gene and transcription factor that initiates a cascade of molecular events that are integral to neuroadaptive responses to cocaine (Nestler, 2001). The Fos gene also represents a crossroads where drug addiction and learning and memory research converge, because C-FOS is similarly upregulated in the hippocampus immediately after a learning event and initiates a cascade of molecular events that are integral to long-term memory formation (Izquierdo and Medina, 1997; Katche et al., 2010). Therefore, HDAC3-mediated $c$-Fos mRNA transcription during CPP conditioning with cocaine may be a possible molecular mechanism by which cocaine strengthens the association of context and drug.

This is the first study to show that NR4A2 (also known as NURR1) may also be involved with HDAC3-mediated cocainecontext memory formation. NR4A2 is an orphan nuclear receptor and transcription factor (for a review of the NR4A family, see Hawk and Abel, 2011). Like C-FOS, NR4A2 is also critical for both learning and memory processes (Peña de Ortiz et al., 2000; von Hertzen and Giese, 2005; Colón-Cesario et al., 2006; McNulty et al., 2012) and reward pathway neuroplasticity (Zetterström et al., 1997; Castillo et al., 1998; Sacchetti et al., 2001). In the latter case, NR4A2 regulates dopamine neuron viability and dopamine neurotransmission in the reward pathway. In an effort to identify a mechanism by which HDAC3 loss enhances memory, McQuown et al. (2011) demonstrated that NR4A2 is absolutely critical for HDAC3-dependent modulation of memory. HDAC $3^{\text {flox/flox }}$ mice with focal deletions in the hippocampus exhibited significantly enhanced memory for a hippocampusdependent task. This enhancement was completely blocked by siRNA against Nr4a2 mRNA delivered to the dorsal hippocampus (McQuown et al., 2011). Nr4a2 was also recently found to be regulated by HDAC3 in the hippocampus during extinction consolidation in mice subjected to cocaine-induced CPP (Malvaez et al., 2013). Therefore, the regulation of Nr4a2 by HDAC3 is important in both the hippocampus (McQuown et al., 2011; Malvaez et al., 2013) and the NAc (this study), suggesting a central mechanism of action for HDAC3 in the regulation of memory.

These data provide the rationale to further investigate whether cocaine-induced histone acetylation occurs in overlapping reward and learning and memory neurocircuits at the promoters of other genes involved in both memory processes and addictionlike behaviors (such as Grin3a). Should that be the case, cocaineinduced histone acetylation may be one mechanism by which strong cocaine-context associative memories are formed. Those memories have been hypothesized to underlie the transformation of cocaine-seeking behaviors into stable, long-lasting behavioral abnormalities characteristic of addiction by facilitating cocaine craving (Everitt and Robbins, 2005; Hyman et al., 2006; McClung and Nestler, 2008). 
This study begins to address a critical question facing epigenetic drug addiction research: which specific HDAC enzyme(s) is involved in mediating cocaine-induced behaviors? The HDAC family is comprised of class I (HDAC1, HDAC2, HDAC3, and HDAC8), class IIa (HDAC4, HDAC5, HDAC7, and HDAC9), class IIb (HDAC6 and HDAC10), class III (the Sirtuins) and class IV (HDAC 11) enzymes (Verdin et al., 2003). As mentioned above, overexpression of class IIa HDAC4 or HDAC5 in the NAc negatively regulates cocaine reward and reinforcement, as measured by CPP and self-administration assays (Kumar et al., 2005; Renthal et al., 2007; Renthal et al., 2009; Wang et al., 2010). HDAC4 was also shown recently to be involved in learning and memory processes (Kim et al., 2012; Sando et al., 2012). Surprisingly, though, it was also shown recently that purified HDAC4 (and possibly the closely related class IIa family member HDAC5) has little to no catalytic activity on canonical HDAC substrates containing acetyl lysines (Lahm et al., 2007). HDAC4 and HDAC5 in vivo may require interactions with the class I HDAC3 and other corepressor proteins in multiprotein complexes to form a functionally active repressor complex, just as they do in vitro (Grozinger and Schreiber, 2000; Guenther et al., 2001; Fischle et al., 2002; for a review see Karagianna and Wong, 2007; Alenghat et al., 2008). In effect, HDAC3 may play a critical role in cocaine-associated neuroplasticity as the potent histone deacetylase in such proposed in vivo complexes.

In summarizing the current literature on HDAC function and memory, we recently proposed the "molecular brake pad" hypothesis (McQuown and Wood, 2011b). This hypothesis posits that HDACs and associated corepressor complexes may function in neurons, in part, as molecular brake pads that act as a persistent clamp that requires strong, activity-dependent signaling (such as cocaine administration) to temporarily release the transcriptional repressor complexes to activate gene expression required for long-term memory formation. Therefore, the deletion or inhibition of specific HDACs is predicted to establish a "permissive" chromatin state that can transform a subthreshold learning event that would not normally result in long-term memory into one that does, generate persistent forms of long-term memory, and facilitate transcription-dependent memory processes. These predictions have been met in the learning and memory literature (Vecsey et al., 2007; Stefanko et al., 2009; Haettig et al., 2011; McQuown et al., 2011).

The data presented in this study provide additional supporting evidence for the molecular brake pad hypothesis. The antiHDAC3 IgG ChIP studies validate the idea that HDAC3 is present at the Fos and Nr4a2 promoters when mice are exposed to the conditioning chamber but not administered cocaine. This is intriguing because without pairing the chamber with cocaine, the mouse will not form a place preference (or associative memory of context with drug). Therefore, in the absence of CPP acquisition (cocaine-context-associated memory formation), HDAC3 is loaded onto the Fos and Nr4a2 promoters at the same time that H4K8Ac levels are minimal and c-Fos and Nr4a2 mRNA expression is low. It takes a powerful signaling event (such as cocainedependent signaling) to relieve HDAC3 association with the promoters, leading to increased levels of $\mathrm{H} 4 \mathrm{~K} 8 \mathrm{Ac}$ (a marker of transcriptional activation) and subsequent $c$-Fos mRNA expression. Interestingly, cocaine-induced upregulation of $\mathrm{Nr} 4 a 2$ mRNA required HDAC3 deletion. Together, these molecular events are strongly correlated with the learned behavior of cocaine-induced CPP acquisition. Finally, as predicted by the molecular brake pad hypothesis, focal homozygous deletions of Hdac 3 in the mouse NAc transform a subthreshold learning event (low dose of cocaine paired with a CPP chamber) that does not normally evince robust CPP acquisition (cocaine-contextassociated memory formation) into one that does lead to robust CPP acquisition.

The study of epigenetic mechanisms involved in cocaine action is an exciting area of investigation because there is so little known about how chromatin modification, and other associated mechanisms involving chromatin remodeling, are involved in cocaine-induced changes in behavior. In summary, this study demonstrates that HDAC3 is a critical negative regulator of cocaine-induced CPP and may be a key enzyme involved in regulating transcription for other memory processes during CPP conditioning that underlies acquisition.

\section{References}

Alaghband Y, Marshall JF (2012) Common influences of non-competitive NMDA receptor antagonists on the consolidation and reconsolidation of cocaine-cue memory. Psychopharmacology (Berl). Advance online publication. Retrieved July 25, 2012. doi:10.1007/s00213-012-2793-y. CrossRef

Alarcón JM, Malleret G, Touzani K, Vronskaya S, Ishii S, Kandel ER, Barco A (2004) Chromatin acetylation, memory, and LTP are impaired in CBP+/- mice: a model for the cognitive deficit in Rubinstein-Taybi syndrome and its amelioration. Neuron 42:947-959. CrossRef Medline

Alenghat T, Meyers K, Mullican SE, Leitner K, Adeniji-Adele A, Avila J, Bućan M, Ahima RS, Kaestner KH, Lazar MA (2008) Nuclear receptor corepressor and histone deacetylase 3 govern circadian metabolic physiology. Nature 456:997-1000. CrossRef Medline

Baltan S, Murphy SP, Danilov CA, Bachleda A, Morrison RS (2011) Histone deacetylase inhibitors preserve white matter structure and function during ischemia by conserving ATP and reducing excitotoxicity. J Neurosci 31:3990-3999. CrossRef Medline

Barrett RM, Malvaez M, Kramar E, Matheos DP, Arrizon A, Cabrera SM, Lynch G, Greene RW, Wood MA (2011) Hippocampal focal knockout of CBP affects specific histone modifications, long-term potentiation, and long-term memory. Neuropsychopharmacology 36:1545-1556. CrossRef Medline

Benekareddy M, Nair AR, Dias BG, Suri D, Autry AE, Monteggia LM, Vaidya VA (2012) Induction of the plasticity-associated immediate early gene Arc by stress and hallucinogens: role of brain-derived neurotrophic factor. Int J Neuropsychopharmacol 16:405-415. CrossRef Medline

Broide RS, Redwine JM, Aftahi N, Young W, Bloom FE, Winrow CJ (2007) Distribution of histone deacetylases 1-11 in the rat brain. J Mol Neurosci 31:47-58. CrossRef Medline

Burger C, Gorbatyuk OS, Velardo MJ, Peden CS, Williams P, Zolotukhin S, Reier PJ, Mandel RJ, Muzyczka N (2004) Recombinant AAV viral vectors pseudotyped with viral capsids from serotypes 1, 2, and 5 display differential efficiency and cell tropism after delivery to different regions of the central nervous system. Mol Ther 10:302-317. CrossRef Medline

Carmack SA, Kim JS, Sage JR, Thomas AW, Skillicorn KN, Anagnostaras SG (2013) The competitive NMDA receptor antagonist CPP disrupts cocaine-induced conditioned place preference, but spares behavioral sensitization. Behav Brain Res 239:155-163. CrossRef Medline

Castillo SO, Baffi JS, Palkovits M, Goldstein DS, Kopin IJ, Witta J, Magnuson MA, Nikodem VM (1998) Dopamine biosynthesis is selectively abolished in substantia nigra/ventral tegmental area but not in hypothalamic neurons in mice with targeted disruption of the Nurrl gene. Mol Cell Neurosci 11:36-46. CrossRef Medline

Colón-Cesario WI, Martínez-Montemayor MM, Morales S, Félix J, Cruz J, Adorno M, Pereira L, Colón N, Maldonado-Vlaar CS, Peña de Ortiz S (2006) Knockdown of Nurr1 in the rat hippocampus: implications to spatial discrimination learning and memory. Learn Mem 13:734-744. CrossRef Medline

Cunningham CL, Gremel CM, Groblewski PA (2006) Drug-induced conditioned place preference and aversion in mice. Nat Protoc 1:1662-1670. CrossRef Medline

Everitt BJ, Robbins TW (2005) Neural systems of reinforcement for drug addiction: from actions to habits to compulsion. Nat Neurosci 8:14811489. CrossRef Medline

Everitt BJ, Belin D, Economidou D, Pelloux Y, Dalley JW, Robbins TW 
(2008) Review. Neural mechanisms underlying the vulnerability to develop compulsive drug-seeking habits and addiction. Philos Trans R Soc Lond B Biol Sci 363:3125-3135. CrossRef Medline

Fischer A, Sananbenesi F, Wang X, Dobbin M, Tsai LH (2007) Recovery of learning and memory is associated with chromatin remodelling. Nature 447:178-182. CrossRef Medline

Fischle W, Dequiedt F, Hendzel MJ, Guenther MG, Lazar MA, Voelter W, Verdin E (2002) Enzymatic activity associated with class II HDACs is dependent on a multiprotein complex containing HDAC3 and SMRT/NCoR. Mol Cell 9:45-57. CrossRef Medline

Freeman WM, Lull ME, Patel KM, Brucklacher RM, Morgan D, Roberts DC, Vrana KE (2010) Gene expression changes in the medial prefrontal cortex and nucleus accumbens following abstinence from cocaine selfadministration. BMC Neurosci 11:29. CrossRef Medline

Green TA, Alibhai IN, Unterberg S, Neve RL, Ghose S, Tamminga CA, Nestler EJ (2008) Induction of activating transcription factors (ATFs) ATF2, ATF3, and ATF4 in the nucleus accumbens and their regulation of emotional behavior. J Neurosci 28:2025-2032. CrossRef Medline

Grozinger CM, Schreiber SL (2000) Regulation of histone deacetylase 4 and 5 and transcriptional activity by 14-3-3-dependent cellular localization. Proc Natl Acad Sci U S A 97:7835-7840. CrossRef Medline

Guan JS, Haggarty SJ, Giacometti E, Dannenberg JH, Joseph N, Gao J, Nieland TJ, Zhou Y, Wang X, Mazitschek R, Bradner JE, DePinho RA, Jaenisch R, Tsai LH (2009) HDAC2 negatively regulates memory formation and synaptic plasticity. Nature 459:55-60. CrossRef Medline

Guenther MG, Barak O, Lazar MA (2001) The SMRT and N-CoR corepressors are activating cofactors for histone deacetylase 3. Mol Cell Biol 21: 6091-6101. CrossRef Medline

Haettig J, Stefanko DP, Multani ML, Figueroa DX, McQuown SC, Wood MA (2011) HDAC inhibition modulates hippocampus-dependent longterm memory for object location in a CBP-dependent manner. Learn Mem 18:71-79. CrossRef Medline

Hawk JD, Abel T (2011) The role of NR4A transcription factors in memory formation. Brain Res Bull 85:21-29. CrossRef Medline

Hyman SE (2005) Addiction: a disease of learning and memory. Am J Psychiatry 162:1414-1422. CrossRef Medline

Hyman SE, Malenka RC, Nestler EJ (2006) Neural mechanisms of addiction: the role of reward-related learning and memory. Annu Rev Neurosci 29:565-598. CrossRef Medline

Izquierdo I, Medina JH (1997) Memory formation: the sequence of biochemical events in the hippocampus and its connection to activity in other brain structures. Neurobiol Learn Mem 68:285-316. CrossRef Medline

Karagianni P, Wong J (2007) HDAC3: taking the SMRT-N-CoRrect road to repression. Oncogene 26:5439-5449. CrossRef Medline

Katche C, Bekinschtein P, Slipczuk L, Goldin A, Izquierdo IA, Cammarota M, Medina JH (2010) Delayed wave of c-Fos expression in the dorsal hippocampus involved specifically in persistence of long-term memory storage. Proc Natl Acad Sci U S A 107:349-354. CrossRef Medline

Kim MS, Akhtar MW, Adachi M, Mahgoub M, Bassel-Duby R, Kavalali ET, Olson EN, Monteggia LM (2012) An essential role for histone deacetylase 4 in synaptic plasticity and memory formation. J Neurosci 32:1087910886. CrossRef Medline

Korzus E, Rosenfeld MG, Mayford M (2004) CBP histone acetyltransferase activity is a critical component of memory consolidation. Neuron 42:961972. CrossRef Medline

Kouzarides T (2007) Chromatin modifications and their function. Cell 128: 693-705. CrossRef Medline

Kumar A, Choi KH, Renthal W, Tsankova NM, Theobald DE, Truong HT, Russo SJ, Laplant Q, Sasaki TS, Whistler KN, Neve RL, Self DW, Nestler EJ (2005) Chromatin remodeling is a key mechanism underlying cocaineinduced plasticity in striatum. Neuron 48:303-314. CrossRef Medline

Lahm A, Paolini C, Pallaoro M, Nardi MC, Jones P, Neddermann P, Sambucini S, Bottomley MJ, Lo Surdo P, Carfí A, Koch U, De Francesco R, Steinkühler C, Gallinari P (2007) Unraveling the hidden catalytic activity of vertebrate class IIa histone deacetylases. Proc Natl Acad Sci U S A 104:17335-17340. CrossRef Medline

Larsen RS, Corlew RJ, Henson MA, Roberts AC, Mishina M, Watanabe M, Lipton SA, Nakanishi N, Pérez-Otaño I, Weinberg RJ, Philpot BD (2011) NR3A-containing NMDARs promote neurotransmitter release and spike timing-dependent plasticity. Nat Neurosci 14:338-344. CrossRef Medline
Levenson JM, O’Riordan KJ, Brown KD, Trinh MA, Molfese DL, Sweatt JD (2004) Regulation of histone acetylation during memory formation in the hippocampus. J Biol Chem 279:40545-40559. CrossRef Medline

Levine AA, Guan Z, Barco A, Xu S, Kandel ER, Schwartz JH (2005) CREBbinding protein controls response to cocaine by acetylating histones at the fosB promoter in the mouse striatum. Proc Natl Acad Sci U S A 102: 19186-19191. CrossRef Medline

Malvaez M, Sanchis-Segura C, Vo D, Lattal KM, Wood MA (2010) Modulation of chromatin modification facilitates extinction of cocaine-induced conditioned place preference. Biol Psychiatry 67:36-43. CrossRef Medline

Malvaez M, Mhillaj E, Matheos DP, Palmery M, Wood MA (2011) CBP in the nucleus accumbens regulates cocaine-induced histone acetylation and is critical for cocaine-associated behaviors. J Neurosci 31: 16941-16948. CrossRef Medline

Malvaez M, McQuown SC, Rogge GA, Astarabadi M, Jacques V, Carreiro S, Rusche JR, Wood MA (2013) HDAC3-selective inhibitor enhances extinction of cocaine-seeking behavior in a persistent manner. Proc Natl Acad Sci U S A.

McClung CA, Nestler EJ (2008) Neuroplasticity mediated by altered gene expression. Neuropsychopharmacology 33:3-17. CrossRef Medline

McGaugh JL (2000) Memory-a century of consolidation. Science 287:248 251. CrossRef Medline

McNulty SE, Barrett RM, Vogel-Ciernia A, Malvaez M, Hernandez N, Davatolhagh MF, Matheos DP, Schiffman A, Wood MA (2012) Differential roles for $\mathrm{Nr} 4 \mathrm{a} 1$ and $\mathrm{Nr} 4 \mathrm{a} 2$ in object location vs. object recognition longterm memory. Learn Mem 19:588-592. CrossRef Medline

McQuown SC, Wood MA (2011b) HDAC3 and the molecular brake pad hypothesis. Neurobiol Learn Mem 96:27-34. CrossRef Medline

McQuown SC, Barrett RM, Matheos DP, Post RJ, Rogge GA, Alenghat T, Mullican SE, Jones S, Rusche JR, Lazar MA, Wood MA (2011) HDAC3 is a critical negative regulator of long-term memory formation. J Neurosci 31:764-774. CrossRef Medline

Nestler EJ (2001) Molecular basis of long-term plasticity underlying addiction. Nat Rev Neurosci 2:119-128. CrossRef Medline

Nestler EJ (2002) Common molecular and cellular substrates of addiction and memory. Neurobiol Learn Mem 78:637-647. CrossRef Medline

Peixoto L, Abel T (2012) The role of histone acetylation in memory formation and cognitive impairments. Neuropsychopharmacology 38 : 62-76. CrossRef Medline

Peña de Ortiz S, Maldonado-Vlaar CS, Carrasquillo Y (2000) Hippocampal expression of the orphan nuclear receptor gene hzf-3/nurrl during spatial discrimination learning. Neurobiol Learn Mem 74:161-178. CrossRef Medline

Pfaffl MW (2001) A new mathematical model for relative quantification in real-time RT-PCR. Nucleic Acids Res 29:e45. CrossRef Medline

Pfaffl MW, Georgieva TM, Georgiev IP, Ontsouka E, Hageleit M, Blum JW (2002) Real-time RT-PCR quantification of insulin-like growth factor (IGF)-1, IGF-1 receptor, IGF-2, IGF-2 receptor, insulin receptor, growth hormone receptor, IGF-binding proteins 1,2 and 3 in the bovine species. Domest Anim Endocrinol 22:91-102. CrossRef Medline

Renthal W, Maze I, Krishnan V, Covington HE 3rd, Xiao G, Kumar A, Russo SJ, Graham A, Tsankova N, Kippin TE, Kerstetter KA, Neve RL, Haggarty SJ, McKinsey TA, Bassel-Duby R, Olson EN, Nestler EJ (2007) Histone deacetylase 5 epigenetically controls behavioral adaptations to chronic emotional stimuli. Neuron 56:517-529. CrossRef Medline

Renthal W, Kumar A, Xiao G, Wilkinson M, Covington HE 3rd, Maze I, Sikder D, Robison AJ, LaPlant Q, Dietz DM, Russo SJ, Vialou V, Chakravarty S, Kodadek TJ, Stack A, Kabbaj M, Nestler EJ (2009) Genomewide analysis of chromatin regulation by cocaine reveals a role for sirtuins. Neuron 62:335-348. CrossRef Medline

Rogge GA, Wood MA (2012) The role of histone acetylation in cocaineinduced neural plasticity and behavior. Neuropsychopharmacology 38: 94-110. CrossRef Medline

Roozafzoon R, Goodarzi A, Vousooghi N, Sedaghati M, Yaghmaei P, Zarrindast MR (2010) Expression of NMDA receptor subunits in human peripheral blood lymphocytes in opioid addiction. Eur J Pharmacol 638:29_ 32. CrossRef Medline

Sacchetti P, Mitchell TR, Granneman JG, Bannon MJ (2001) Nurrl enhances transcription of the human dopamine transporter gene through a novel mechanism. J Neurochem 76:1565-1572. CrossRef Medline

Sando R 3rd, Gounko N, Pieraut S, Liao L, Yates J 3rd, Maximov A (2012) 
HDAC4 governs a transcriptional program essential for synaptic plasticity and memory. Cell 151:821-834. CrossRef Medline

Stefanko DP, Barrett RM, Ly AR, Reolon GK, Wood MA (2009) Modulation of long-term memory for object recognition via HDAC inhibition. Proc Natl Acad Sci U S A 106:9447-9452. CrossRef Medline

Swank MW, Sweatt JD (2001) Increased histone acetyltransferase and lysine acetyltransferase activity and biphasic activation of the ERK/RSK cascade in insular cortex during novel taste learning. J Neurosci 21:3383-3391. Medline

Taniguchi M, Carreira MB, Smith LN, Zirlin BC, Neve RL, Cowan CW (2012) Histone deacetylase 5 limits cocaine reward through cAMPinduced nuclear import. Neuron 73:108-120. CrossRef Medline

Vecsey CG, Hawk JD, Lattal KM, Stein JM, Fabian SA, Attner MA, Cabrera SM, McDonough CB, Brindle PK, Abel T, Wood MA (2007) Histone deacetylase inhibitors enhance memory and synaptic plasticity via CREB: CBP-dependent transcriptional activation. J Neurosci 27:6128-6140. CrossRef Medline
Verdin E, Dequiedt F, Kasler HG (2003) Class II histone deacetylases: versatile regulators. Trends Genet 19:286-293. CrossRef Medline

von Hertzen LS, Giese KP (2005) Memory reconsolidation engages only a subset of immediate-early genes induced during consolidation. J Neurosci 25:1935-1942. CrossRef Medline

Wang L, Lv Z, Hu Z, Sheng J, Hui B, Sun J, Ma L (2010) Chronic cocaineinduced $\mathrm{H} 3$ acetylation and transcriptional activation of CaMKIIalpha in the nucleus accumbens is critical for motivation for drug reinforcement. Neuropsychopharmacology 35:913-928. CrossRef Medline

Wood MA, Kaplan MP, Park A, Blanchard EJ, Oliveira AM, Lombardi TL, Abel T (2005) Transgenic mice expressing a truncated form of CREBbinding protein (CBP) exhibit deficits in hippocampal synaptic plasticity and memory storage. Learn Mem 12:111-119. CrossRef Medline

Zetterström RH, Solomin L, Jansson L, Hoffer BJ, Olson L, Perlmann T (1997) Dopamine neuron agenesis in Nurr1-deficient mice. Science 276: 248-250. CrossRef Medline 